\title{
Uršula Lipovec Čebron (ur.) \\ KULTURNE KOMPETENCE IN ZDRAVSTVENA OSKRBA \\ Priročnik za razvijanje kulturnih kompetenc zdravstvenih delavcev

\author{
Ljubljana, Nacionalni inštitut za javno zdravje, 2016
}

Slovensko zdravstvo lahko k svoji večji učinkovitosti pripomore tudi skozi sistematično razvijanje znanj in spretnosti zdravstvenih delavcev na nekaterih področjih, ki doslej niso bila dovolj tematizirana niti v dodiplomskem niti v vseživljenjskem izobraževanju zaposlenih. Gre predvsem za zajemanje iz bogate zakladnice znanja družboslovnih in humanističnih ved, ki pretežno naravoslovno-medicinsko izobraženim strokovnjakom omogoča razvoj sposobnosti za učinkovito delo s kulturno raznolikimi uporabniki zdravstvenega varstva.

V letu 2016 je Nacionalni inštitut za javno zdravje v Ljubljani izdal priročnik, ki naj bi zdravstvenim delavcem pomagal pri razvoju njihovih kulturnih kompetenc. Napisala ga je skupina avtoric in avtorja (Martina Bofulin, Jerneja Farkaš Lainščak, Karmen Gosenca, Ajda Jelenc, Marjeta Keršič Svetel, Uršula Lipovec Čebron, Sara Pistotnik, Juš Škraban in Darja Zaviršek), ki je v okviru projekta »Za boljše zdravje in zmanjšanje neenakosti v zdravju « s finančno podporo Norveškega finančnega mehanizma sodelovala pri prizadevanjih za razvoj nekaterih vidikov slovenskega zdravstva. Priročnik je bil že praktično preizkušen ob usposabljanju zdravstvenih delavcev v treh zdravstvenih domovih v Sloveniji.

Zajetna knjiga, ki obsega 252 zelo lepo oblikovanih strani formata A4, je z velikimi črkami, večbarvnim tiskom, poudarjenimi okvirčki z besedilom in vključenim slikovnim gradivom do bralk in bralcev zelo prijazna. Želi biti komunikativna, želi spodbuditi zanimanje, listanje, branje in uporabo pri vsakdanjem delu zdravstvenih delavcev. Ne nazadnje že predgovor opozarja na dejstvo, da je pojem kulturne kompetentnosti v slovenskem zdravstvu novejši ter da še ni široko poznan in uveljavljen pri zdravstvenih delavcih $\mathrm{v}$ nasprotju z mnogimi državami v Evropi in širše, kjer pomeni sistematično sestavino zdravstvenega izobraževanja in delovanja (Betancourt, Green in Carillo, 2002).

Kulturne kompetence avtorice in avtor opredeljujejo kot »skupek znanj in veščin v odnosih z ljudmi, ki posamezniku omogoči, da izboljša svoje razumevanje, občutljivost, sprejemanje, spoštovanje in odzivanje na kulturne razlike in odnose, ki iz njih izhajajo. Kulturna kompetenca omogoča nudenje bolj kakovostne zdravstvene oskrbe in pomaga, da bolje sodelujem z ljudi iz različnih kultur.«(Berkley Diversity, 2015) Gre za zavedanje 
o vpetosti v lastno kulturo in refleksijo lastnih predsodkov, stereotipov in prepričanj, poznavanje drugih kultur in za veščine medkulturnega sodelovanja.

Uvodoma ravno na podlagi izkušenj od drugod avtorji opozarjajo na nekatere možne pasti usposabljanja za kulturne kompetence, kot so nevarnost prepričanja, da gre tu za tehnično veščino, ki jo je mogoče pridobiti s kratkim tečajem, ali nereflektiranost lastne kulturne pripadnosti in zamejenosti zdravstvenih delavcev, pa tudi nevarnost, da bi s pojmom kulturne raznolikosti relativizirali in navidezno omilili socialne neenakosti in deprivilegiranosti nekaterih družbenih skupin.

Priročnik je razdeljen na sedem poglavij. V prvem avtorji obravnavajo pomen kulturnih kompetenc za zdravstveno oskrbo. Izhajajo iz nekaterih zmot o kulturnih kompetencah ter s primeri osvetlijo prednosti kulturno kompetentne zdravstvene oskrbe in njen pomen za izide pri pacientih. Pomembno je njihovo opozorilo, da je razmislek o lastni kulturni pripadnosti ključen za učinkovito delovanje tako zdravstvenih delovnih organizacij kot zdravstvenih delavcev, tako posameznikov kot poklicnih skupin (kot opozarja npr. Hall, 2005).

Drugo poglavje je namenjeno opredelitvi osrednjega koncepta priročnika - kulture. Za nekatere bralce je to nekoliko pozno v tekstu, po drugi strani pa je najbrž pred tem pomembno začeti s kulturnimi kompetencami kot praktičnim dosežkom usposabljanja in zagristi v teoretične definicije šele nekoliko kasneje. Opredelitve se začnejo z vsakdanjim pojmovanjem kulture in zlagoma gradijo vsebino tega pojma, ki ga po Unescu (2001, str. 34) opredelijo kot »množico raznolikih duhovnih, materialnih, intelektualnih in čustvenih značilnosti družbe ali družbene skupine, ki poleg umetnosti in literature obsega tudi življenjske sloge, načine sobivanja, sisteme vrednot, tradicije in prepričanja«. Sprehod skozi besedne in slikovne metafore kulture pripelje do vprašanja, kako se kultura kaže na področju zdravja in bolezni in kaj je medicina kot kultura. Ta uvid je, kot rečeno, ključni pogoj kulturne kompetentnosti zdravstvenih delavcev pri zagotavljanju zdravstvene oskrbe raznolikih uporabnikov.

Delo se nadaljuje s poglavjem, usmerjenim na osnovni »predmet dela « v zdravstvu, to je človeško telo. Uvodoma predstavi nekatera razširjena prepričanja o telesu in nadaljuje z opozorilom o kulturni določenosti odnosa do nekaterih telesnih značilnosti, kot sta spol in hendikep. Predstave in prepričanja o zgradbi in delovanju telesa ter njegovih mejah se v laični javnosti precej razlikujejo od znanja zdravstvenih delavcev, kar lahko povzroča nesporazume, če se zdravstveni delavci tega ne zavedajo.

Natančneje je obravnavana povezava kulture, zdravja in bolezni ter izkušnja bolezni. Na relaciji med slabim počutjem kot laični paradigmi oziroma razlagalnim modelom in boleznijo kot medicinsko paradigmo lahko nastanejo nesporazumi, ki ovirajo ustrezno zdravstveno obravnavo.

V posebnem poglavju se avtorji dotaknejo nekaterih drugih kulturnih vidikov zdravstvene obravnave, kot so odnos do bolečine in do avtonomije posameznika pri odločanju o zdravljenju, vloga vere in duhovnosti ter prehrana. Gre za obsežne in pomembne teme, 
ki so tu zajete pod oznako »druge«, pa bi gotovo vsaka zase zaslužile podrobnejšo in bolj poglobljeno obravnavo.

Predzadnje poglavje zajame snov nekoliko širše od kulturološke perspektive, saj v osnovno tematiko obravnave uvede družbenoekonomske dejavnike, kot sta revščina in migracija.

Zadnje poglavje je posvečeno komuniciranju med zdravstvenimi delavci in uporabniki ter pomenu kulturnih kompetenc za njegovo učinkovitost. Posebej obravnava nekatere specifične oblike komuniciranja, kot so tolmačenje za potrebe določenih družbenih skupin (jezikovno ali kako drugače različnih), medkulturno mediatorstvo in zagovorništvo. Poglavje sklene opozorilo o vlogi zdravstvenega sistema v oskrbi ranljivih skupin s standardom za zagotavljanje enakosti v zdravstveni oskrbi.

$\mathrm{Z}$ delom Kulturne kompetence in zdravstvena oskrba $\mathrm{v}$ slovenski prostor v sistematični obliki vstopa pojem kulturnih kompetenc, ki je v svetu znan že od osemdesetih let, ko so postali pozorni na težave pri komuniciranju s pacienti drugih narodnosti, jezika, prepričanj in vrednot (Cross, Bazron, Dennis in Isaacs, 1989). Posebna dragocenost pričujočega dela pa je $v$ tem, da se sicer opira na tuje vire, da pa zajema tudi iz konkretnih situacij v slovenskem zdravstvu in njegove kulturne raznolikosti. K temu je pripomogla neposredna vpetost avtoric in avtorja v klinično okolje. Prav tako je bilo tudi samo pisanje priročnika posebna medkulturna izkušnja, saj je povezalo strokovnjake $\mathrm{z}$ različno izobrazbo in poklicno potjo, ki so svoja besedila oblikovali tudi na podlagi izkušenj pri praktičnem usposabljanju zdravstvenih delavcev za kulturne kompetence. Prav očitni vpliv te žive medsebojne izmenjave naredi priročnik še posebej zanimiv in aktualen.

Ciljna skupina bralcev priročnika so zdravstveni delavci različnih poklicev in stopenj izobrazbe, ki želijo v svoje delo vključiti znanja in spretnosti za preseganje kulturnih razlik. Priročnik je zato oblikovan tako, da bralcem kar najbolj olajša vstop v kulturno kompetentno zdravstveno obravnavo. V vseh poglavjih so izhodiščne točke vsakdanja, običajna razumevanja pojmov, ki so pogosto omejena in/ali zmotna. Skozi številne primere (zlasti zanimivi so tisti iz slovenskega okolja), vprašanja za razmišljanje, vprašanja za samooceno, naloge, usmeritve na videogradivo in ideje za aktivnosti je bralcem omogočeno dejavno in poglobljeno spremljanje snovi. Na koncu vsakega zaokroženega dela knjige so avtorice in avtor strnili sezname priporočil za kulturno kompetentno obravnavo. Tudi seznami literature omogočajo dodatno poglobitev in razširitev posameznih tem, saj je seveda obravnavana problematika tako široka, da bi mnoge teme zaslužile ločene priročnike - npr. kulturna pogojenost odločanja pacientov glede zdravljenja, prehrambne navade, specifika duhovnih potreb ipd.

Knjigi je priložen DVD z intervjuji s predstavniki ali zastopniki nekaterih posebnih družbenih skupin, kot so osebe brez zdravstvenega zavarovanja, brezdomci, Legebitra, migranti in HIV pozitivne osebe. Ta dodatek še poveča njeno nazornost in uporabnost.

Ob tem pa je treba opozoriti tudi na omejenost uporabe koncepta kulturnih kompetenc za učinkovito zdravstveno obravnavo. Kulturne kompetence res lahko izboljšajo 
komunikacijo in zmanjšajo možnost za neustrezno obravnavo zaradi nerazumevanja pomena kulturnih specifičnosti, ne morejo pa zmanjšati dejanskih socialnoekonomskih razlik in lahko celo zabrišejo dejanski vir problemov. A to dejstvo ne zmanjšuje pomena in dragocenosti priročnika - vključitev znanja o kulturno kompetentni zdravstveni oskrbi v znanje in delovanje slovenskih zdravstvenih delavcev bo olajšala njihovo delo, izboljšala položaj uporabnikov in povečala učinkovitost obravnave.

\section{Majda Pahor}

\section{LITERATURA}

Berkley Diversity (2015). Glossary of terms. Pridobljeno s http://diversity.bercley.edu/glossary-terms.

Betancourt, J. R., Green, A. R. in Carillo, J. E. (2002). Cultural competence in health care: emerging frameworks and practical approaches. New York: The Commonwealth Fund.

Cross, T. L., Bazron, B. J., Dennis, K. W. in Isaacs, M. R. (1989). Towards a culturally competent system of care: a monograph on effective services for minority children who are severely emotionally disturbed. Washington: Georgetown University Child Development Center, CASSP Technical Assistance Center.

Hall, P. (2005). Interprofessional teamwork: Professional cultures as barriers. Journal of Interprofessional Care, 19(1), 188-96.

Unesco (2001). Univerzalna deklaracija o kulturni raznolikosti. Pariz: Organizacija Združenih narodov za izobraževanje, znanost in kulturo. Pridobljeno s http://www.eksena.si/ splosna-deklaracija-o-kulturni-raznolikosti/. 